\title{
The technology of designing plastic windows and their transport from Poland since 1990
}

\author{
Rafał Karaś1) (ORCID ID 0000-0003-0726-1185) \\ DOI: dx.doi.org/10.14314/polimery.2021.1.3
}

\begin{abstract}
PVC window and door constructions are more and more popular in architecture. The profile manufacturing technology, structure and materials are constantly being modified. The Author analyses technological changes that have been implemented within the period of the last 20 years on the basis of Polish market experience, where the technology of PVC window and door production was hardly known, in relation to the largest producer and exporter of such products in the European Union at present. The Author also suggests that the area under investigation demands special care within material engineering, transport and ecology.
\end{abstract}

Keywords: plastics, composites, windows, doors, transport.

\section{Technologia konstrukcji okien z tworzyw polimerowych i ich transport z Polski od 1990 roku}

Streszczenie: Konstrukcje okienne i drzwiowe z tworzyw polimerowych są coraz bardziej powszechne w budownictwie. Technologia wykonania kształtowników, jak również ich budowa oraz stosowane materiały podlegają ciągłym modyfikacjom. Na postawie doświadczeń rynku polskiego, w odniesieniu do największego producenta i eksportera tego rodzaju produktów na terenie Unii Europejskiej, przeanalizowano zmiany technologiczne wdrażane w tym obszarze na przestrzeni ostatnich 20 lat. Zwrócono uwagę na potrzebę objęcia tego obszaru produkcji nadzorem w zakresie inżynierii materiałowej, transportu i ekologii.

Słowa kluczowe: tworzywa polimerowe, kompozyty, okna, drzwi, transport.

The aim of the paper is to analyse the development of window production technology on the basis poly(vinyl chloride) profiles. The analysis concerns changes in the construction and shapes of profiles, research susceptibility of window construction and changes in legal regulations since 1989. The analysis was worked out with respect to the technology and size of production and window transportation within the area of the European Union. The Author in recapitulation of the thorough research suggests directions of the development of window profiles that can be applied in future. The concepts presented here have not been undertaken in technical context up to now. The Author claims that the present development in window and door production branch out of PVC profiles in Poland has a direct impact on the situation in the European Union the branch under investigation.

\section{HISTORICAL VIEW}

In 1990, Poland transformed its economy into a freemarket one. As a result, migration of new production tech- nologies and materials became possible. Availability of new technological ideas, cutting-edge technical solutions and modern production machinery resulted in a dynamic growth of production companies and new technological opportunities. Production of windows and doors made of rigid poly(vinyl chloride) (PVC) became a rapidly developing sector of economy at that time. The situation concerning the production of windows and doors was unique as many windows and doors production plants were established in Poland in a short period. However, components such as profiles, hardware or thermal insulation glazing were imported mainly from other countries in Central Europe, including Germany and Austria. This happened because during the times of communism in Poland doors and windows were mainly made of wood and window glass were made by rolling. Moreover, there had been no legal and technical regulations concerning PVC windows and doors in Poland. There had been no production standards, technical or installation tests.

New conditions and possibilities for private economic activities encouraged the flow of new technologies from

1) WSB University at Dąbrowa Górnicza, Cieplaka 1c, 41-300 Dąbowa Górnicza, Poland.

e-mail: rkaras@wsb.edu.pl,rafal.karas@gmail.com 
other countries to Poland. The new technologies of window and door production are based on plastic instead of wood. The only way of the introduction of the new technologies was to get the Technical Approval for windows and doors made from rigid poly(vinyl chloride) and Technical Approval for windows and doors made from PVC profiles. Initially, all tests were performed at the Research Building Institute. Having obtained the Technical Approval the producers still had to get the certificate (now - the certificate of compliance). The process of introducing new technologies took a lot of time and was very expensive. Any changes concerning profile construction, chemical composition or technological change in production process needed independent technical opinion and the consent of the institution that issues technical approval or/and the certificate [1].

Companies that were interested in product export had to get through similar procedure in each of the individual countries. The necessity of sample tests followed from different technical demands in each country. In most areas in Poland the required pressure and wind suction strength was about $300 \mathrm{~Pa}$, while in neighbouring Slovakia the requirements reached the level of about $600 \mathrm{~Pa}$. As the tests at that time were not respected interchangeably the producer had to go through the window and door certification process within the area of each country [2-4].

Currently in Polish market windows and doors can be admitted to trade and use in several Polish institutions. Apart from that foreign institutions open their branches within the area of Poland. Polish institutions are for example Institute of Building Technology in Warsaw, Institute of Ship Technology in Gdańsk, Mobile Laboratory of Building Technology, Laboratory of Building Technology in Dąbrowa Górnicza. There is also a branch of German IFT Rosenheim Laboratory recently opened in Poland, situated in Kęty. Additionally, since the introduction of a harmonized standard PN/EN 14351 there has been the possibility of testing window construction in any research institute within the EU countries, who has the authority to issue a certificate of compliance. This document has to be issued by every country that belong to the European Union. A simplification for producers is also the introduced "cascading" principle, which means that the system provider such as Veka AG, Aluplast, Gealan, Schücko, Thyssen Polymer, Salamander, Brügmann that completed tests in any relevant research unit within the EU territory can pass the possibility of the use of tests to the producer. All the changes in legal and technical evaluation of a product described here facilitate transport and installation of windows produced in Poland [5]

Initially, German companies manufacturing and supplying plastic sections, such as Veka, Aluplast, Kommerling, Rechau, Trockal, Thyssen Polymer, Schücko, Salamander and Brüngmann secured a dominant position on the Polish market. The key role in the development of plastic processing technologies, such as cutting, welding and milling in Poland was played by machinery manufacturers, mainly from Germany, such as Rotox, Rapid, Urban or Hollinger. In this review, we discuss this area which deserves to be taught as a constituent to Materials Science and Engineering [6].

The technological window manufacturing standard that had been set by the market originally was a frame and casement made of "three-chamber" PVC sections. The universally applied technologies used were, e.g. frames made of extruded PVC profiles with dimensions of approximately $6 \mathrm{~cm}$ by $6 \mathrm{~cm}$ and $6 \mathrm{~cm}$ by $8 \mathrm{~cm}$ for casements. In such profiles, there were three air-filled chambers, hence the three-chamber name. The example is presented in Fig. 1 [7].

The standard length of such profiles was $600 \mathrm{~cm}$ or $650 \mathrm{~cm}$. As the economy and technical condition of buildings in Poland were very poor, the demand for such windows was increasing by several dozen percent each year. Therefore, as part of international technological expansion, Veka company (Skierniewice) in 1994, Deceunink (Swarzędz) in 2005 and Aluplast (Poznań) in 1995 established their branches in Poland and, with time, began the production of profiles there. Initially, the produced pro- a)

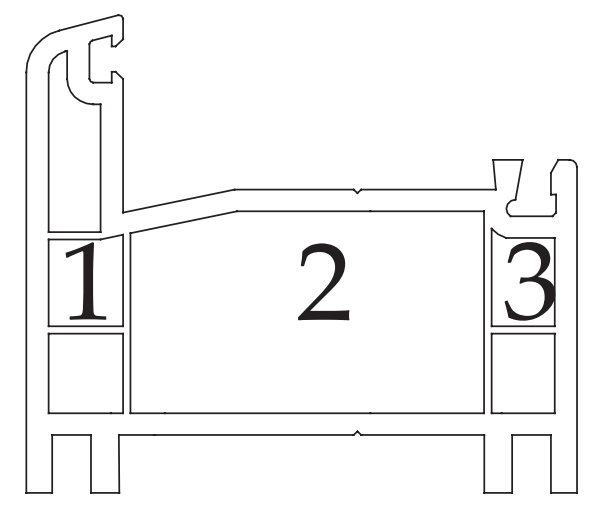

b)

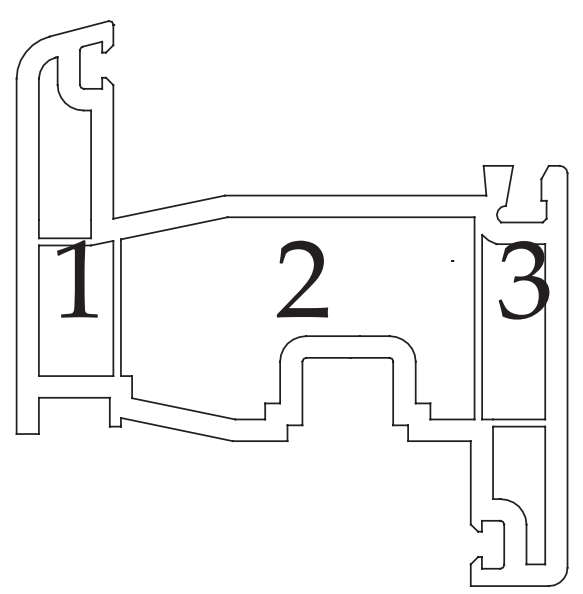

Fig. 1. Design of three-chamber PVC sections: a) three-chamber frame, b) three-chamber casement 
files were white and made of non-plasticized PVC. This method consisted in the extrusions of white profiles after heating the granulate imported from the parent company in Germany. Then, as the materials became plastic, it was formed and got its proper shape after being cooled down due to thermal shrinking. In subsequent years in Poland many other companies producing PVC profiles started their manufacturing plants, e.g. in 2004 - Gealan (Rzgów) and DECCO Extrusion (Suwałki). In the scope of the development of technological knowledge concerning manufacturing and extrusion of PVC systems the production started also in window manufacturing companies, such as Dobroplast in 2005 (Zambrów), Drutex - in 2007 (Bytów), Budwar - Centrum (CKM Extrusion) in 2016 (Zduńska Wola) [8, 9].

\section{QUALITY TESTS FOR WINDOWS AND DOORS}

\section{General quality tests}

The quality of manufactured windows is verified using test machines for testing the tightness of entire structures and test machines for testing the strength of corners of welded profiles. The tightness test involves fixing the test sample (the entire window) in a chamber, where overpressure is created from the outside of the window. In addition, the window is sprinkled with water. As a result of the increasing pressure on the structure, leakage occurs after some time. The border line for the positive test result is considered to be the pressure value up to which the leakage has not occurred. The place of leakage from the technical point of view is the weakest point of the examined structure (Fig. 2) [5].

Initially, since 1990, manufacturers had a limited opportunity to inspect the quality of their products. None of the manufacturers had their research stations, they had their tests performed in academic institutions. However, the tests were very expensive, therefore the scale of tests was limited. In order to test their constructions, most of the manufacturers used the services of test system providers from Western Europe, from whom they received profiles or hardware. Lack of research facilities

a)

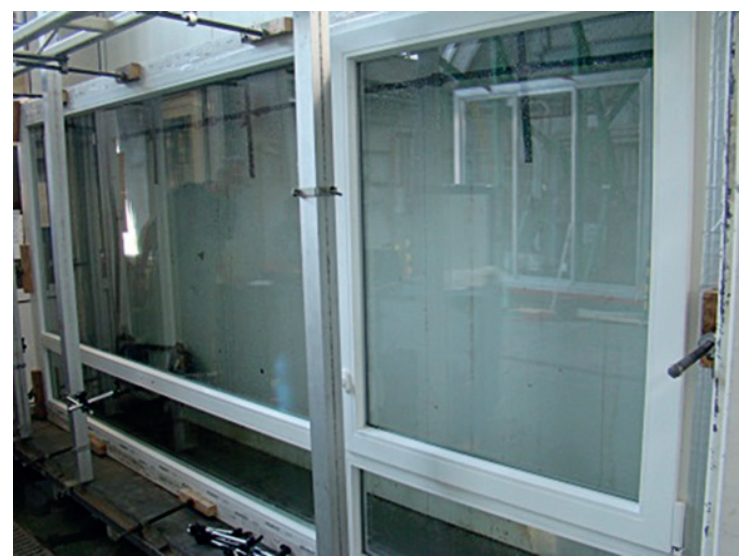

forced manufacturers to have leak tests and rigidity tests performed by companies abroad [10, 11].

This practice was common until 22 October 2010, when PN-EN 14351:2010 standard was introduced. This standard was a breakthrough in technical assessment of windows. Technological changes and modifications implemented under the influence of marketing activities very often caused errors in the published technical parameters. To combat this, the European Union established PN-EN 14351:2010 standard [5, 10, 11].

\section{PVC welding quality tests}

The strength of the welded profiles is examined by special testing machines, where the cut corners of thermally joined profiles due to pressure undergo ultimate tensions. The conducted investigation allows for the estimation of the strength of thermal joint of PVC profiles in the process of window production.

In order to carry out ongoing profile welding quality tests, most of the manufacturers have a device for breaking corners. This device controls the quality of work of welding machines, which melt the profiles on mirrors layered with PTFE (polytetrafluoroethylene) and, as a result of melting and pressing, the profiles are joined.

In order to obtain the required strength of corners, the above parameters should match the composition of PVC mix or composites using such a mix. Samples must be prepared according to the following principle:

$L n-$ length of the section in neutral axis of the profile,

$L z$ - length of the corner's arm from the outer side,

$B$ - distance between trucks axles,

$W$ - profile section's strength towards the direction of the load,

$e$-distance of the terminal fiber of the piece,

$\sigma-$ fracture stress,

$F$ - minimum fracture stress value.

Plastic materials, depending on the temperature, are characterized by brittleness and limited impact resistance, therefore plastic manufacturing parameters are fundamental for the achieved results (Figs. 3 and 4) $[10,11]$.

b)

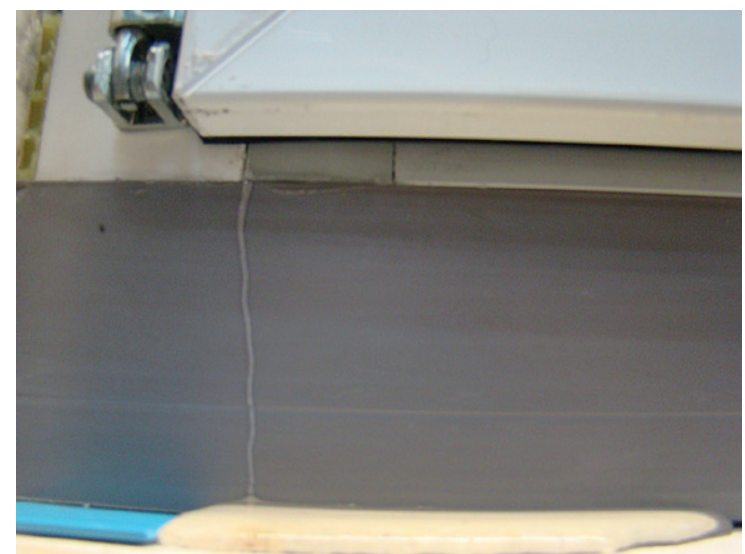

Fig. 2. PVC window construction test and place of leakage: a) PVC window test, b) place of leakage 


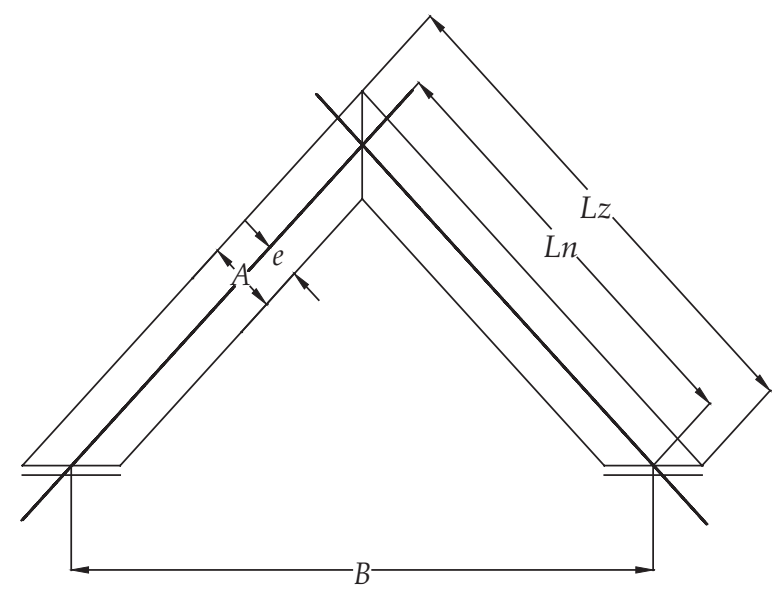

Fig. 3. Test sample outline

\section{DEVELOPMENT OF PRODUCTION TECHNOLOGY FOR PROFILES MADE OF RIGID PVC}

The next stage of development of PVC window and door profiles production technology was lamination with wood-like laminates. This technology consisted in lamination of PVC profiles with foil (e.g. resembling wood). As a result of this technological process, windows resembling wooden windows (e.g. walnut, cherry, beech or any other color) either from the outside or the inside could be manufactured (Fig. 5).

Soon enough, due to availability and quickly-changing consumer preferences, Poland became the "testing ground" for "colored" windows, that were not used in the EU very often. Nationwide interest and demand for windows and doors in colors other than white facilitated further increase in production on a scale much larger than in any other European country. Aluplast was one of the first companies to develop the technology of lamination of white sections in Poland. Other companies, such as Veka or Kommerling, exported white and colored profiles manufactured using the so called coextrusion technology, which consisted in extrusion (coextrusion) of PVC profiles with a layer of pre-dyed PVC. The dyed

a)

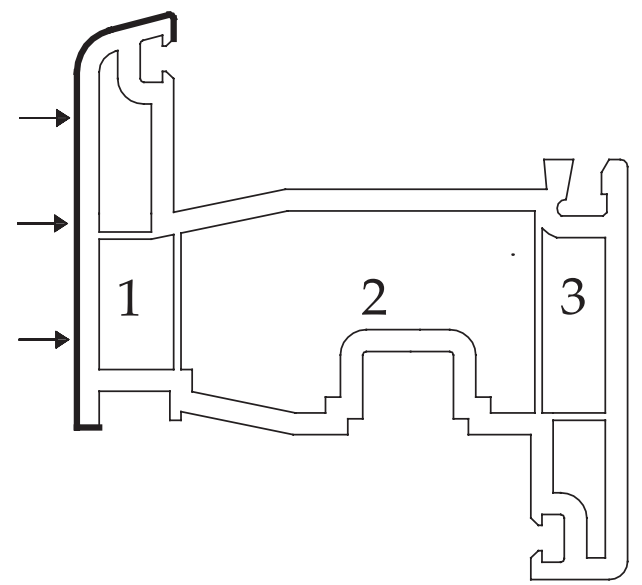

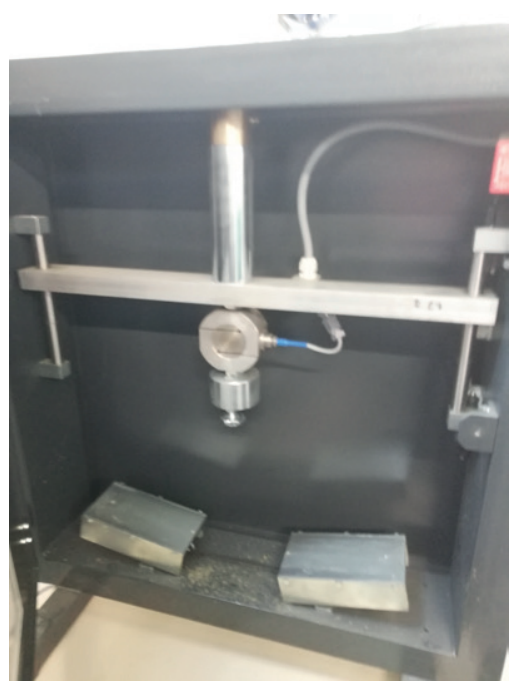

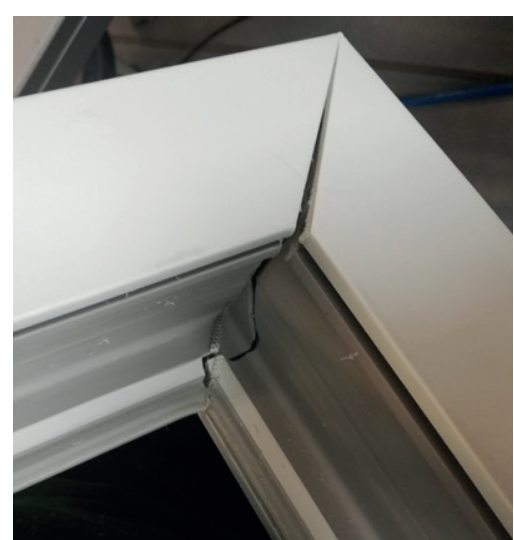

Fig. 4. Welded corners strength test: a) machine for corner testing, b) strength test

layer was on the outside of the window or door surface. Thanks to this, white and colored profiles had a dyed, $c a$. $1 \mathrm{~mm}$ thick PVC layer. Laminate was then glued to such prepared profiles $[12,13]$.

The next modification to the extrusion technology was the replacement of dyed PVC with PMMA. This technology was introduced to the market by Gealan company. In comparison with PVC profiles, PVC + PMMA composite have better impact resistance and heat up slower. Thanks b)

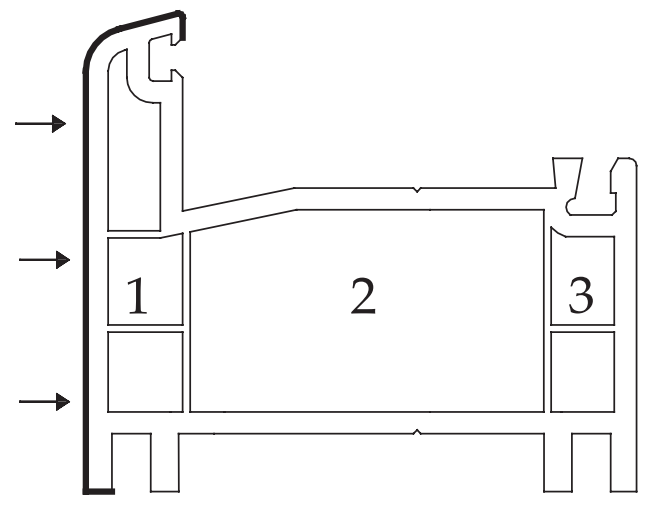

Fig. 5. Laminated three-chamber profiles: a) laminated three-chamber frame, b) laminated three-chamber casement 
a)

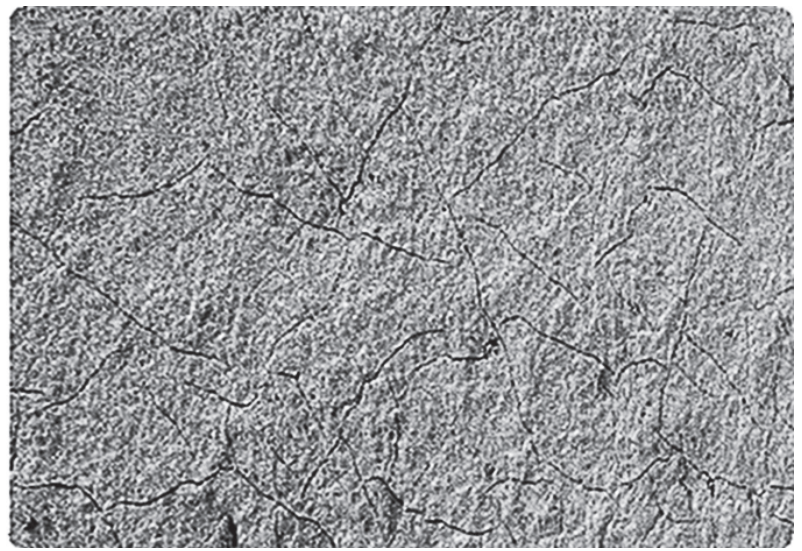

b)

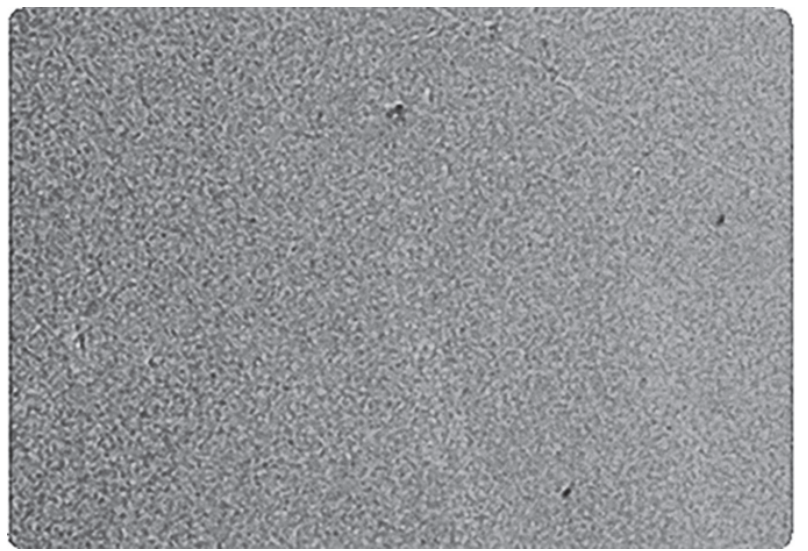

Fig. 6. Microscopic examination of sections after 10 years of use: a) microscopic examination of PVC surface after 10 years of use, b) microscopic examination of PMMA surface after 10 years of use

a)

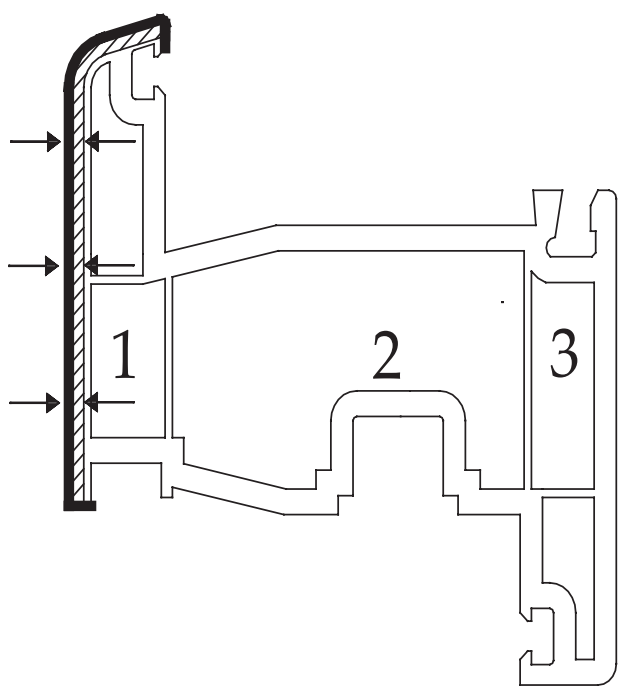

b)

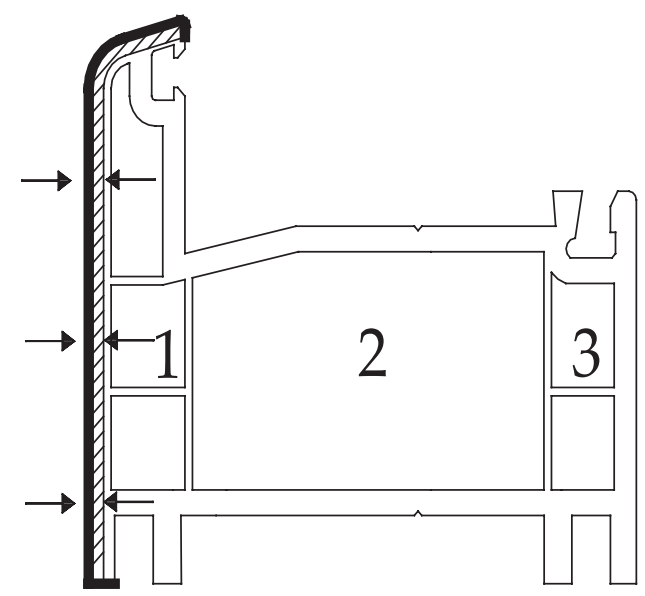

Fig. 7. Profiles with a layer of dyed PVC (coextrusion): a) laminated three-chamber frame with coextrusion, b) laminated three-chamber casement with coextrusion

to those properties, such profiles are more resistant to "aging" of material, as proven by comparative tests of PVC profiles and composites with PMMA outer layer after 10 years. The photos of the tested samples are presented in Fig. 6 [14, 15].

As the profiles with PMMA surface heat up slower and have better resistance to solar UV radiation, such profiles show less surface defects and breaks and lesser degradation.

Both described technologies (colored PVC coextrusion and PMMA coextrusion) are currently available outside Poland (Fig. 7).

In 2000, when the European Union announced the so called green book, there was again a technological change in the production of PVC profiles. The change concerned the PVC stabilizers used. Lead and cadmium-based stabilizers used in the production of PVC profiles were replaced with calcium and zinc stabilizers. The change was introduced due to the concern for ecologic safety and human health. An additional requirement was to include recycled materials as well in the manufacture of PVC sections. Veka was the first company in Europe to develop automatic recycling of material from old windows in a closed circuit. It was a technological breakthrough, which began in 1993, when the company opened a factory recycling PVC material from Germany.

Currently companies such as Veka AG (Germany) and Deceunik (Belgium) have factories that take care of the recycling process of the whole old PVC windows removed and delivered. In the material recovery windows and doors are ground together with glass, steel, seals, etc., and then in the process of separation individual materials are distinguished. Window recycling factories are established in the European Union countries, where this technology is used longer because at the moment the old PVC windows are replaced by the new ones. The recycling process in these factories is completely automated and finally the PVC is divided into fractions of colours similar to white, grey and brown. The technologies of automatic recycling described here are proprietary tech- 
a)

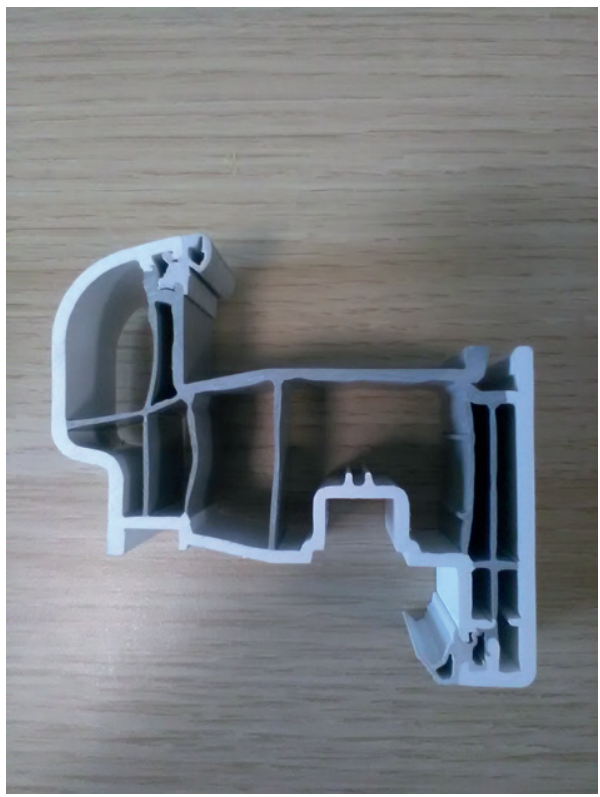

b)

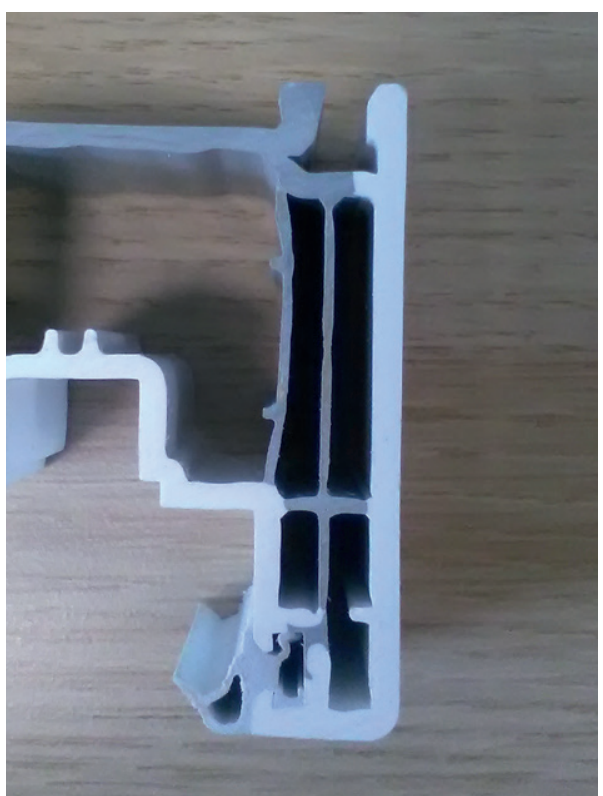

Fig. 8. Profiles with recycled PVC core: a) profile with recycled PVC core, b) close-up on coextrusion

nical solutions and are connected with the implementation of the requirements described in the so-called green book of plastics.

The fact of availability of recycled material made the technology of coextrusion (co-manufacture) of PVC and the recycled PVC profiles popular both in Poland and generally in the European Union. The modification of the extrusion technology employing recycled materials consisted in that the recycled material was inside the profiles (in the core - often in grey color) and on the outer surface, there was the original material, as presented in Fig. 8.

Further development of the technology is aimed at the manufacture of composites using wood flour or glass fibers. The evolution of the technology results from the increase of material strength while maintaining high thermal insulation parameters [16-18].

a)

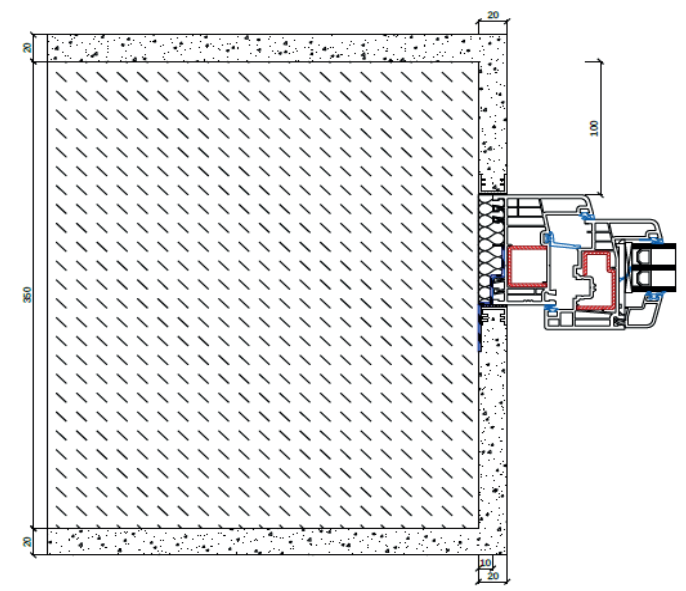

\section{TRENDS IN TECHNOLOGICAL CHANGES IN THE PRODUCTION OF WINDOWS AND DOORS PROFILES}

Currently the directions of the development of the technology of production and transport of profiles are determined by the PN-EN 14351:2010 standard set by the regulation concerning technical conditions imposed on buildings and their location. The mentioned document sets the guidelines for thermal permeability that window and door constructions should meet. In order to comply with the requirements simulation tests of temperature distribution in fitted windows and doors are carried out (Fig. 9) [5, 7, 19].

The parameter of the required thermal permeability has a significant impact on the shape of the new pro-

b)

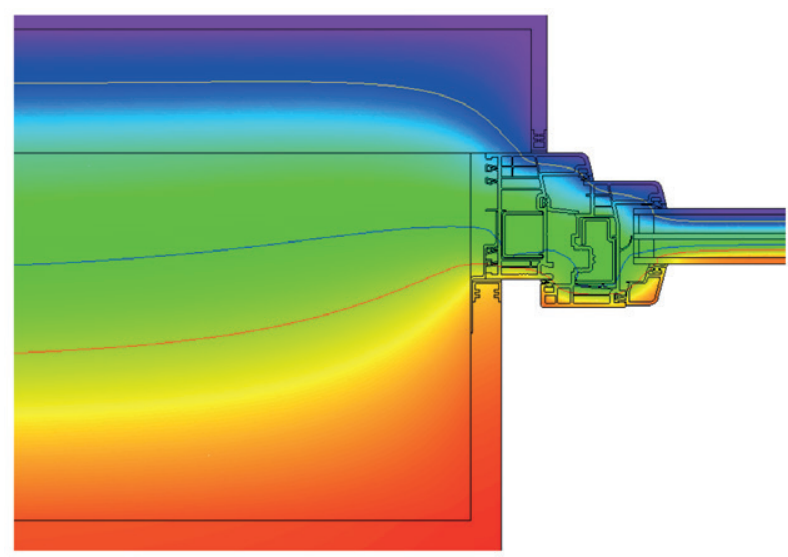

Fig. 9. Simulation test of temperature distribution: a) picture of profiles fitted in walls, b) the result of simulation test of temperature distribution within $\left(-10^{\circ} \mathrm{C}\right.$ outside the building $-+20^{\circ} \mathrm{C}$ inside the building) 
a)

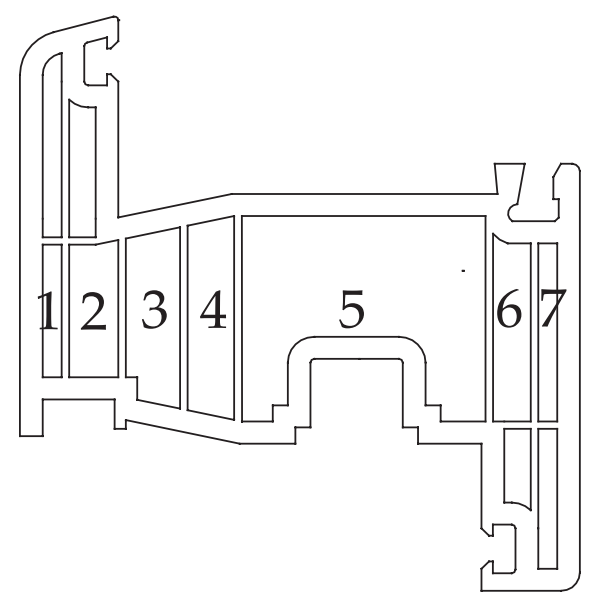

b)

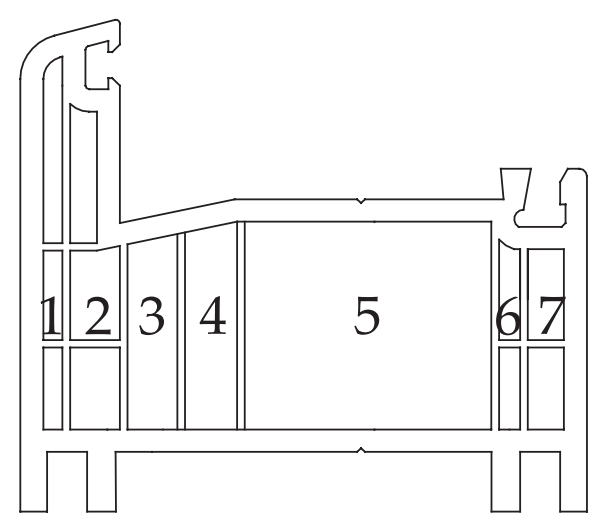

Fig. 10. Seven-chamber profile design (frame and casement): a) seven-chamber frame, b) seven-chamber casement

files. Any change in the geometry or material is closely connected with the requirements set for producers by the European Union both nowadays and in future, especially with respect to the $\mathrm{CO}_{2}$ emission. The Table 1 presents the parameters of thermal permeability demanded from windows in the period being analyzed in Poland.

a)

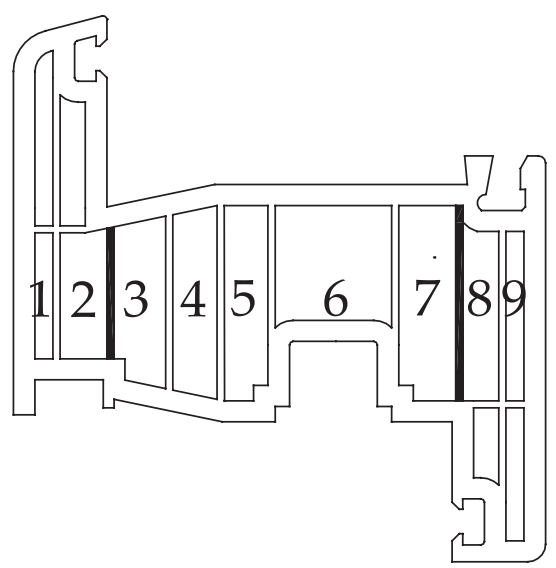

At present the parameters of thermal permeability of windows set for Poland are one of the most strict in Europe. The high expectations concerning technical parameters in Poland induce the necessity of further technical development of window profiles used by producers [20, 21].

b)

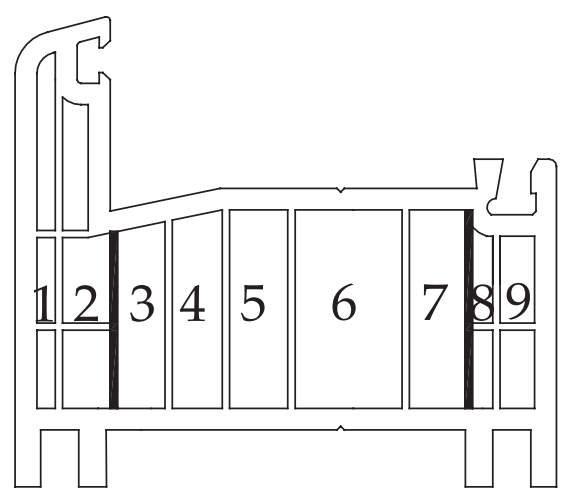

Fig. 11. Design of nine-chamber profiles with a reinforcing flat bar in the frame: a) nine-chamber frame with aluminum flat bars, b) nine-chamber casement with aluminum flat bars

a)

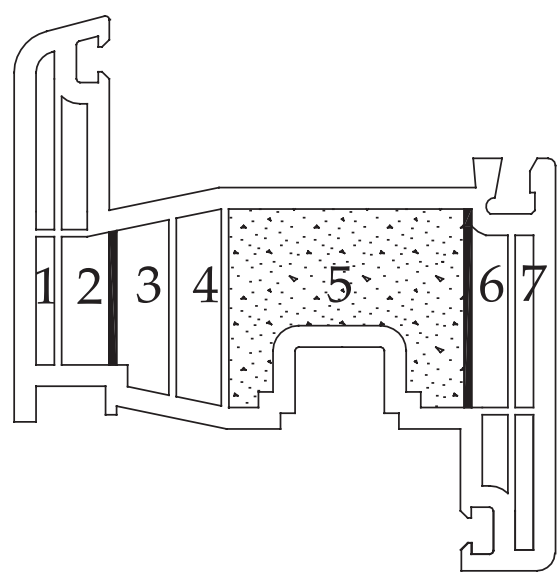

b)

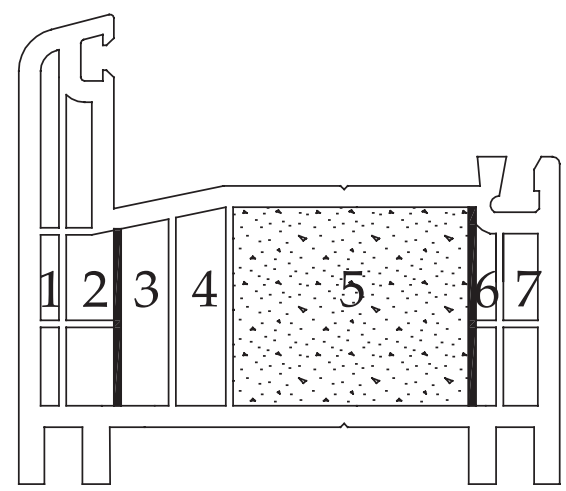

Fig. 12. Design of seven-chamber profiles filled with PUR foam with a reinforcing flat bar in the frame and in the casement: a) seven-chamber frame with aluminum flat bars and PUR foam, b) seven-chamber casement with aluminum flat bars and PUR foam 
As it was necessary to achieve parameters complying with the regulations in individual countries and PN-EN 14351:2010 standard, such as the heat transfer coefficient, the manufacturers started to "widen" the profiles so there is more room inside (air voids), which improves heat properties (Table 1) [1, 5].

$\mathrm{T}$ a b 1 e 1. Heat transfer requirements in the years 2006-2021

\begin{tabular}{c|c|c|c|c}
\hline Year & 2006 & 2014 & 2017 & 2021 \\
\hline $\begin{array}{c}\text { Window heat transfer } \\
\text { coefficient, } \mathrm{W} /\left(\mathrm{m}^{2} \cdot \mathrm{K}\right)\end{array}$ & 1.8 & 1.4 & 1.1 & 0.9 \\
\hline
\end{tabular}

In order to improve the parameters, some companies (Gealan, Aluplast) also started to pump PUR foam into the profiles, use the so-called aerogels (OKNOPLAST window manufacturer) or to foam TPS gaskets (Drutex window manufacturer). Profile manufacturers also modified the extrusion technology consisting in profile coextrusion with aluminum flat bars (Schücko, Aluplast) or profile extrusion with the use of glass fiber composites (Aluplast) (Figs. 10, 11, 12) [22, 23].

\section{SUMMARY}

While developing technologies for window production, transport, assembly and operation based on PVC, laminated PVC, dyed profiles and profiles with PMMA layer, Polish windows and doors manufacturers, such as Oknoplast Kraków, Oknoplus, Vetrex, or MS Poznań acquired know-how related to finished products. The knowledge acquired during the above period enabled them to secure domestic demand and facilitate transport to neighboring European countries. In this way, Poland witnessed an "expansion" of Polish manufacturers to neighboring markets and in the year 2015, Poland became the largest exporter of windows and doors, leaving all EU countries behind, as presented in Table 2 [24].

T a b l e 2. Export value of windows and doors in the European Union

\begin{tabular}{c|c|c}
\hline $\begin{array}{c}\text { Position } \\
\text { of export } \\
\text { in the EU }\end{array}$ & Country & $\begin{array}{c}\text { Export value } \\
\text { in millions of euro }\end{array}$ \\
\hline 1 & Poland & 2247.66 \\
2 & Germany & 1779.54 \\
3 & Italy & 612.80 \\
4 & The Netherlands & 496.56 \\
5 & Austria & 412.13 \\
6 & Portugal & 351.70 \\
7 & Czech Republic & 315.36 \\
8 & Romania & 257.45 \\
9 & Denmark & 251.20 \\
10 & Slovakia & 232.39 \\
11 & Spain & 230.07 \\
12 & Belgium & 222.77
\end{tabular}

\begin{tabular}{l|c|c}
13 & Estonia & 218.72 \\
14 & Lithuania & 178.61 \\
15 & Slovenia & 174.45 \\
\hline
\end{tabular}

\section{FINAL REMARKS}

The Author claims that trends in profile development will concern the parameters of thermal permeability, ecology, composite materials and transport security. To meet the permeability requirements the PVC producers are going to make the profiles wider so that the additional air chambers can be created. The additional air chambers will positively affect the thermal permeability parameters of the profiles. Another option for the profile development is to fill the inside with the PUR foam or materials possessing the properties of aerogels. One should remember that any development of the PVC profiles has to be carried out in accordance with ecological requirements. For these reasons the percentage of the recycled material will increase in the profiles. In addition, in order to reduce the negative effects of plastics used in construction, the profiles will have to be adapted to the process of automatic recycling. The factories specializing in the recycling of old windows and doors will probably be established in each of the European Union countries.

As doors and windows from Polish producers are transported for long distances abroad, the crucial point is to make the journey secure. Therefore, parallel to PVC window and door production development, window and door protection manufacture for security in transport has also been developed. The protection is especially needed for window frame and has to be adapted to the weight and size of the PVC profile construction $[25,26]$.

The development of composite profiles is also becoming a common solution, in which their durability is improved by connecting the PVC profiles with, e.g. aluminum overlays mounted from outside. The improvement of the durability of the PVC profiles with aluminum overlays results from the limitation of their heating and protection against the UV radiation. In the future there will be also further development of the composite profiles based on the possibility of connections of PVC profiles and wooden profiles. Joining materials such as PVC and wood has a positive effect on structures using the properties of thermal isolation of PVC and wood rigidity [27-30].

Technological development of the future profiles used for window and door production is directed towards meeting new challenges concerning additional requirements for the construction. In particular, the profile construction should respond to dangers in different aspects, therefore they must have anti-burglar properties, fire andevacuation properties, and bullet-proof protection.

At present the Author develops works concerning technologies directed towards higher performance parameters for complex PVC constructions. 
Further research works are connected with the development of production technology and the construction of composite profiles will be presented in the next articles.

\section{ACKNOWLEDGMENTS}

In particular, I would like to thank Professor Witold Brostow for consultations and helpful comments during the writing of this paper.

\section{REFERENCES}

[1] Lis P., Lis A.: Okno 2003, 1, 10.

[2] Brostow W., Hagg Lobland H.E., Khoja S.: Materials Letters 2015, 159, 478.

https://doi.org/10.1016/j.matlet.2015.07.047

[3] Makarewicz M.: Świat Szkła 2008, 4, 34.

[4] Płoński J.: Świat Szkła 2006, 11, 34.

[5] PN-EN 14351-1:2010 „Okna i drzwi - Norma wyrobu, właściwości eksploatacyjne”.

[6] Bubień J.: Okno 1990, 1, 97.

[7] Karaś R., Michlowicz E.: „Problemy Inżynierii Mechanicznej i Robotyki" (Ed. Wolny S.), 2006, p. 155. ISBN 83-89772-21-3.

[8] Mieczkowski P.: Okno 2006, 3, 12.

[9] Okno 2004, 4, 10.

[10] Konstantinov A., Verkhovsky A.: IOP Conference Series Materials Science and Engineering 2020, 753, 032022.

https://doi.org/10.1088/1757-899X/753/3/032022

[11] Konstantinov A., Verkhovsky A.: IOP Conference Series Materials Science and Engineering 2020, 753, 022092. https://doi.org/10.1088/1757-899X/753/2/022092

[12] Brostow W., Osmanson T.: Materials Letters: X 2019, 1, 100005. https://doi.org/10.1016/j.mlblux.2019.100005

[13] Brostow W., Hagg Lobland H.E.: "Materials: Introduction and Applications", Wiley, 2017.

[14] Brostow W., Hagg Lobland H.E., Narkis M.: Journal of Materials Research 2006, 21 (9), 2422. http://10.1557/jmr.2006.0300

[15] Brostow W., Hagg Lobland H.E.: Journal of Materials Science 2010, 45 (1), 242. http://dx.doi.org/10.1007/s10853-009-3926-5

[16] Kozłowski M., Macyszyn J., Karaś R.: „Biokompozyty z surowców odnawialnych" (Eds. Kuciel S., Rydarowski H.), Politechnika Krakowska, Kraków 2012, pp. 184-199.

[17] Macyszyn J., Karaś R., Kozłowski M.: „Współczesne metody i techniki w badaniach systemów inżynieryjnych", Drukarnia Oficyny Wydawniczej Politechniki Wrocławskiej, Wrocław 2011, pp. 29-32, ISBN 978-83929704-4-6.

[18] Kozłowski M., Kozłowska A., Frąckowiak S.: Polimery 2010, 55, 726. http://dx.doi.org/10.14314/polimery.2010.726

[19] Tian G., Fan Y., Zhang X. et al.: Journal of Engineered Fibers and Fabrics 2020, 15. https://doi.org/10.1177/1558925020911005

[20] Czajka Z.: Okno 2002, 4, 102.

[21] Ierardi L., Liuzzi S., Stefanizzi P.: International Journal of Heat and Technology 2017, 17, S252. https://doi.org/10.18280/ijht.35Sp0135

[22] Łakota K.: Okno 2005, 4, 32.

[23] Kisielewicz T.: Okno 2003, 2, 54.

[24] ASM Centrum badań i analizy rynku lata 2017, 2018.

[25] „Ekoefektywność technologii” (Ed. Kleiberg M.), Wydawnictwo Naukowe Instytutu Technologii Eksploatacji-Państwowego Instytutu Badawczego, Radom 2011, pp. 18-23, ISBN 978-83-7789-050-9.

[26] „Recykling tworzyw sztucznych w Europie” (Ed. Kozłowski M.), Politechnika Wrocławska, Wrocław 2006, pp. 197-215. ISBN 8370859593.

[27] Shnawa H.A.: Journal of Thermal Analysis and Calorimetry 2020, 139, 125. https://doi.org/10.1007/s10973-019-08365-8

[28] Nanib M.N., Marouane A.-S., Abdelmoula M.: International Journal of Production Research 2011, 49, 2265. https://doi.org/10.1080/00207541003620386

[29] Prochowski L., Żuchowski A.: „Technika transportu ładunków", Wydawnictwa Komunikacji i Łączności, 2016, pp. 39-46.

[30] Cichosz M.: "Logistics Management", Oficyna Wydawnicza SGH, Warszawa 2015, pp. 93-114.

Received 19 VIII 2020. 